Original Research

\title{
Initial Start-up Characteristics of Anaerobic Ammonium Oxidation in a UASB Reactor
}

\author{
Huiyu Cheng ${ }^{1}$, Yunan Yan ${ }^{1}$, Xiang Yi ${ }^{1}$, Jing Wang ${ }^{2}$, Wenlai Xu ${ }^{1,3 *}$, Haisong Nie ${ }^{3 * *}$ \\ ${ }^{1}$ State Key Laboratory of Geohazard Prevention and Geoenvironment Protection, \\ Chengdu University of Technology, Chengdu, China \\ ${ }^{2}$ Sichuan Shutong Geotechnical Engineering Company-Water Resources and Environmental \\ Engineering Company, Chengdu, China \\ ${ }^{3}$ Department of International Environmental and Agricultural Science, Tokyo University \\ of Agriculture and Technology, Tokyo, Japan
}

Received: 3 June 2019

Accepted: 25 July 2019

\begin{abstract}
Anammox (anaerobic ammonium oxidation) is a promising technology to remove nitrogen from wastewater, but the long start-up time limits its practical application. This study used an up-flow anaerobic sludge bed (UASB) reactor, selected anaerobic granular sludge as inoculating sludge, and maintained $\mathrm{pH}(7.8-8.2)$, temperature $\left(30-35^{\circ} \mathrm{C}\right)$, and $\mathrm{DO}\left(\leq 0.5 \mathrm{mg} \mathrm{L}^{-1}\right)$ to start an anammox process. The initial start-up process occurred in three stages: cell lysis phase, activity lag phase, activity elevation phase. In the cell lysis (1-2 d) and activity lag (3-4 d) phases, denitrification was the main reaction and TN removal rates were $36.72 \%$ and $52.34 \%$, respectively. In the activity elevation phase (5-30 d), denitrification weakened, anammox activity strengthened, $\mathrm{NH}_{4}^{+}-\mathrm{N}$ removal rate was increased greatly, $\mathrm{NO}_{2}^{-}-\mathrm{N}$ removal rate took on the trend of increasing at first and decreasing later, and the average removal rate of TN rose to $74.33 \%$ and reached the maximum rate of $81.91 \%$. The variations of sludge bed in the cell lysis phase and activity lag phase were not obvious; but in the activity elevation phase, the sludge bed gradually varied from the bottom to the top, and the color of the sludge changed from black to brown, and a little sludge was red.
\end{abstract}

Keywords: anammox, UASB reactor, start-up, anaerobic granular sludge, biological removal of nitrogen

\section{Introduction}

Anaerobic ammonium oxidation (anammox) refers to the biological nitrogen removal process in which anaerobic ammonium oxidation bacteria (AnAOB)

*e-mail: xuwenlai2012@cdut.cn

**e-mail: nie-hs@cc.tuat.ac.jp oxidize $\mathrm{NH}_{4}^{+}$directly into $\mathrm{N}_{2}$ with $\mathrm{NO}_{2}^{-}$as electron acceptor in anaerobic conditions [1-2].

$$
\begin{gathered}
\mathrm{NH}_{4}^{+}+1.32 \mathrm{NO}_{2}^{-}+0.066 \mathrm{HCO}_{3}^{-}+0.13 \mathrm{H}^{+} \\
\rightarrow 1.02 \mathrm{~N}_{2}+0.256 \mathrm{~N}_{2}+0.066 \mathrm{CH}_{2} \mathrm{O}_{0.5} \mathrm{~N}_{0.15}+2.03 \mathrm{H}_{2} \mathrm{O}
\end{gathered}
$$

This technology is very promising, featuring no need for aeration, no need for additional carbon resources, high nitrogen removal efficiency, low sludge yield and small floor area [3-4]. As reported, the cost 
of the technology to remove $1 \mathrm{~kg}$ of nitrogen was only 0.75 euro, which was far lower than that of the traditional nitrification-denitrification process (the cost of $1 \mathrm{~kg}$ nitrogen is 2-5 euros) [5].

However, the generation time (15-30 d) of AnAOB is long [6], and AnAOB is sensitive to temperature [7], $\mathrm{pH}$ [8], dissolved oxygen [9], substrate concentration [10] and other environmental factors [11]. Therefore, the start-up time of anammox technology is long, which seriously limits the application of anammox [12]. Thus, it is critical to study the fast start-up and mechanism of anammox technology.

Researchers have made relevant research on reactor type [13], inoculating sludge source [14], operation parameters [15-16] and other aspects [17] for the fast start-up of Anammox, and thus have achieved some conclusions on the influential factors of the fast startup of Anammox, but the theoretical explanation is not adequate, and researchers vary in their conclusions. In conclusion, further study on the fast start-up of Anammox is necessary.

The research showed that AnAOB exists universally in natural [18-19] and artificial ecosystems [20-21]. Previous studies have used aerobic activated sludge [22], nitrification sludge [23], denitrifying granular sludge [24] and anaerobic granular sludge [25] used as inoculum. These studies have reported that it consistently took several months or longer to achieve satisfactory anammox performance. Retaining anammox biomass is critical for the stable operation of the anammox process due to the slow growth rate of bacterial population [26]. Compared to flocs, granules have a higher biomass density, higher settling velocities and a more regular shape [27]. In addition, granular sludge provides a high biofilm-specific surface area and the geometry and free movement of granules limits external boundary layer resistances, promoting mass transfer of substrate toward the organisms [27]. Moreover, the growing conditions of anaerobic granular sludge and anammox bacteria are similar, so anaerobic granular sludge has more potential anammox bacterial strains. Thus, anaerobic granular sludge was selected as the inoculating sludge in this experiment.

AnAOBs have long generation time and easily wash out, so the sludge-holding capacity of the reactor is very important. An up-flow anaerobic sludge bed (UASB) can effectively reduce the loss of sludge by hydraulic shear force and its special three-phase separator, which can promote the fast start-up of an anammox reactor [28]. Thus, a UASB reactor was selected in our study.

From what is analyzed above, this study used anaerobic granular sludge as the inoculating sludge and UASB reactor with excellent sludge-holding capacity as an anammox start-up reactor to explore nitrogen removal performance, sludge change and nitrogen removal mechanism in the initial start-up period. We aimed to provide references to the fast start-up of anammox technology.

\section{Material and Methods}

\section{Reactor Setup and Operation}

An up-flow anaerobic sludge bed (UASB) was selected to enrich anammox sludge in our study. The reactor, shown in Fig. 1, is made of organic glass, with the total height of $145 \mathrm{~cm}$ and work volume of $4.5 \mathrm{~L}$. The height in the reaction zone is $100 \mathrm{~cm}$, the inner diameter is $7 \mathrm{~cm}$ and the work volume is $2 \mathrm{~L}$, and a row of sampling ports are set every $25 \mathrm{~cm}$ in the vertical direction. The top of the reactor is covered and sealed with bolt and adhesive tape. Gas is discharged by threephase separator pores. Water bath heating system with thermostatic control is installed on the outer layer of the reactor: the heater provides temperature, the diving pump circulates water, and the temperature controller controls temperature at $30 \pm 5^{\circ} \mathrm{C}$. In addition, the reactor is wrapped with silver paper to prevent the retarding effect of AnAoB.

The reaction influent water was pumped in from the bottom with a peristaltic pump, and the effluent water was drained away from the upper outlet. The $\mathrm{pH}$ of the influent water was adjusted to 7.5-8.0 with $0.1 \mathrm{~mol}^{-1}$ hydrochloric acid. AnAOB are sensitive to oxygen, and can only exist in the condition of less than $5 \%$ (take the oxygen saturation in the air as 100\%) oxygen saturation of oxygen partial pressure. Once the oxygen partial pressure is higher than $18 \%$ oxygen saturation, the activity is restrained. Thus, synthetic wastewater is purged with nitrogen for $15-20 \mathrm{~min}$ to remove dissolved nitrogen and keep the concentration of dissolved nitrogen less than $0.5 \mathrm{mg} \mathrm{L}^{-1}$.

In addition, if we increase the nitrogen load by shortening HRT to increase the influent ammonium and nitrite concentrations, the flow speed of the water would increase, and thus more dissolved oxygen

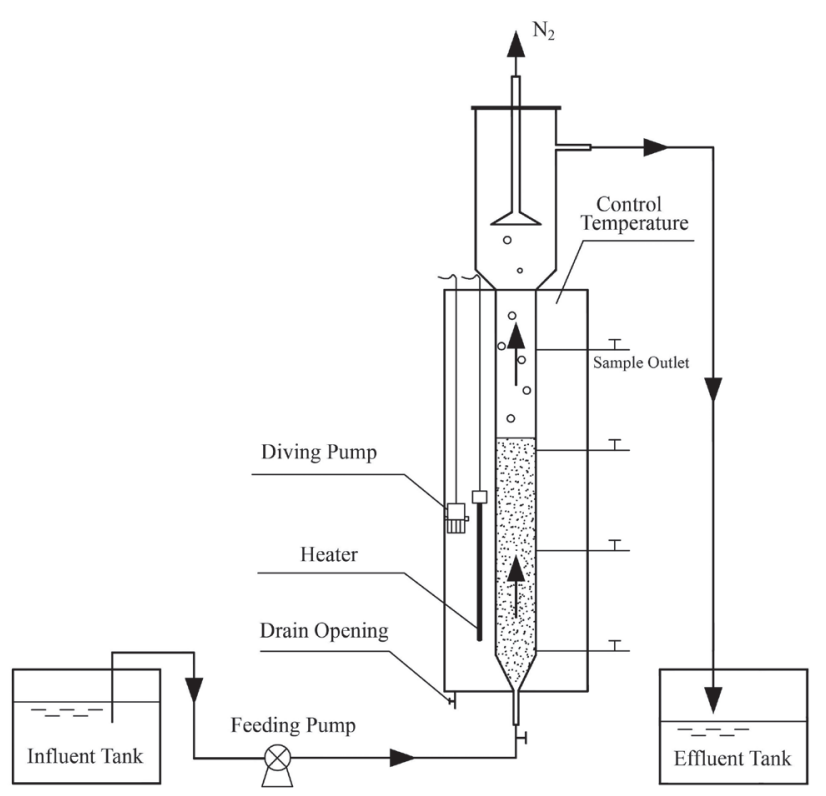

Fig. 1. Schematic diagram of the UASB reactor. 
Table 1. Constitution of simulated wastewater for anaerobic ammonium oxidation.

\begin{tabular}{|c|c|c|c|}
\hline Constitution & Concentration $\left(\mathrm{g} \mathrm{L}^{-1}\right)$ & Constitution & Concentration $\left(\mathrm{g} \mathrm{L}^{-1}\right)$ \\
\hline Substrate & & Trace elements & $1.25 \mathrm{~mL} \mathrm{~L}^{-1}$ \\
\hline $\mathrm{NH}_{4} \mathrm{Cl}$ & Add as needed & $\mathrm{H}_{3} \mathrm{BO}_{4}$ & 0.014 \\
\hline $\mathrm{NaNO}_{2}$ & Add as needed & $\mathrm{MnCl}_{2} \cdot 4 \mathrm{H}_{2} \mathrm{O}$ & 0.99 \\
\hline $\mathrm{KHCO}_{3}$ & 0.6 & $\mathrm{CuSO}_{4} \cdot 5 \mathrm{H}_{2} \mathrm{O}$ & 0.025 \\
\hline Minerals & & $\mathrm{ZnSO}_{4} \cdot 7 \mathrm{H}_{2} \mathrm{O}$ & 0.43 \\
\hline $\mathrm{KH}_{2} \mathrm{PO}_{4}$ & 0.01 & $\mathrm{NiCl} \cdot 6 \mathrm{H}_{2} \mathrm{O}$ & 0.19 \\
\hline $\mathrm{CaCl}_{2} \cdot 2 \mathrm{H}_{2} \mathrm{O}$ & 0.1 & $\mathrm{NaMoO}_{4} \cdot 2 \mathrm{H}_{2} \mathrm{O}$ & 0.22 \\
\hline $\mathrm{MgSO}_{4} \cdot 7 \mathrm{H}_{2} \mathrm{O}$ & 0.3 & $\mathrm{NaSeO}_{4} \cdot 10 \mathrm{H}_{2} \mathrm{O}$ & 0.123 \\
\hline Trace elements I & $1.25 \mathrm{~mL} \mathrm{~L}^{-1}$ & $\mathrm{CoCl}_{2} \cdot 6 \mathrm{H}_{2} \mathrm{O}$ & 0.3 \\
\hline EDTA & 15 & $\mathrm{NaWO}_{4} \cdot 2 \mathrm{H}_{2} \mathrm{O}$ & 0.664 \\
\hline $\mathrm{FeSO}_{4} \cdot 7 \mathrm{H}_{2} \mathrm{O}$ & 5 & & \\
\hline
\end{tabular}

would enter the reactor. Thus, our research started up the UASB reactor by directly increasing the influent nitrogen. The initial concentrations of $\mathrm{NH}_{4}^{+}-\mathrm{N}, \mathrm{NO}_{2}^{-}-\mathrm{N}$ are respectively $30 \mathrm{mg} \mathrm{L}^{-1}$ and $40 \mathrm{mg} \mathrm{L}^{-1}$, and HRT is $24 \mathrm{~h}$.

\section{Synthetic Wastewater and Seed Sludge}

This experiment adopted model wastewater. $\mathrm{NH}_{4}^{+}-\mathrm{N}$ and $\mathrm{NO}_{2}^{-}-\mathrm{N}$ are provided by $\mathrm{NH}_{4} \mathrm{Cl}$ and $\mathrm{NaNO}_{2}$, respectively, and are added according to needs. The specific constitution is shown in Table 1 .

The inoculated sludge was anaerobic granular sludge (AGS) taken from a starch sewage treatment works, wherein VSS is $13.57 \mathrm{~g} \mathrm{~L}^{-1}$, SS is $18.62 \mathrm{~g} \mathrm{~L}^{-1}$ and $\mathrm{VSS} / \mathrm{SS}$ is $72.8 \%$. The color of the sludge is black, and the granular diameter is $0.5-2 \mathrm{~mm}$ (Fig. 2a). Observed from a microscope (Fig. 1b), the boundary of the sludge is clear and the structure is compact. Before inoculation, AGS were washed several times with buffer solution $\left(0.5 \mathrm{~g} \mathrm{~L}^{-1} \mathrm{KHCO}_{3}\right)$ to remove impurities and floating sludge.
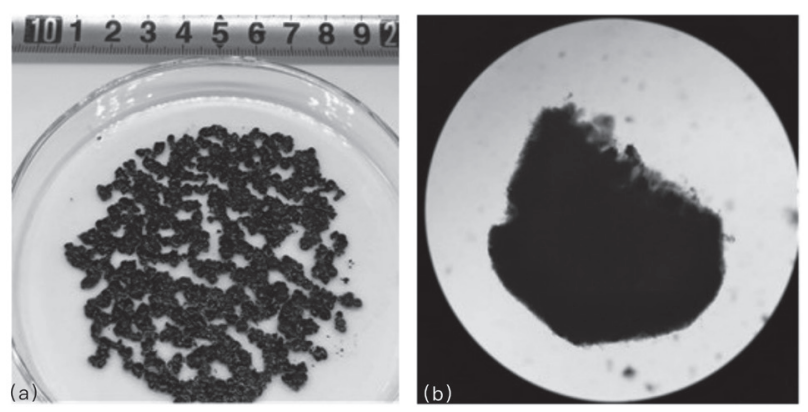

Fig. 2. Inoculated sludge: a) Observed from culture vessel; b) Observed from microscope $(\times 100)$.

\section{Analytical Methods}

UASB performance was monitored every day by measuring the concentrations of $\mathrm{NH}_{4}^{+}-\mathrm{N}, \mathrm{NO}_{2}^{-}-\mathrm{N}$, $\mathrm{NO}_{3}^{-}-\mathrm{N}$, and $\mathrm{TN}$ in the influent and effluent, which were determined according to standard methods (APHA 2005) [29]. Before chemical analysis, the samples were filtered through $0.45 \mu \mathrm{m}$ filters, and each sample was conducted in quadruplication.

DO was measured using a dissolved oxygen meter (WTW Company, Germany). Suspended solids (SS) and volatile suspended solids (VSS) were measured according to Standard Methods (APHA 2005) [29].

The exterior condition of the granular sludge was observed with an optical microscope (model Leica DMLB) and shot with an Olympus digital camera.

\section{Results and Discussion}

\section{Performance of Nitrogen Removal during the Start-up of Anammox}

The experiment lasted for $30 \mathrm{~d}$. The transfer and conversion performances of each nitrogen contaminant are shown in Fig. 3. In the start-up process of anammox, the consumption of the substrate takes on evident features that can be divided into 4 stages [30], namely cell lysis, activity lag, activity elevation and stationary. As shown in Fig. 3, this experiment has experienced the lysis and lag phases, and now is in the elevation phase.

The 1-2 d was in the cell lysis phase. In this phase, the influent $\mathrm{NH}_{4}^{+}-\mathrm{N}$ and $\mathrm{NO}_{2}^{-}-\mathrm{N}$ were respectively controlled around $30 \mathrm{mg} \mathrm{L}^{-1}$ and $40 \mathrm{mg} \mathrm{L}^{-1}$. The effluent $\mathrm{NH}_{4}^{+}-\mathrm{N}$ was a little higher than that of the influent, and the average concentration was $35.61 \mathrm{mg} \mathrm{L}^{-1}$. The effluent concentration of nitrite was low, and the average concentration was $9.61 \mathrm{mg} \mathrm{L}^{-1}$, and there 

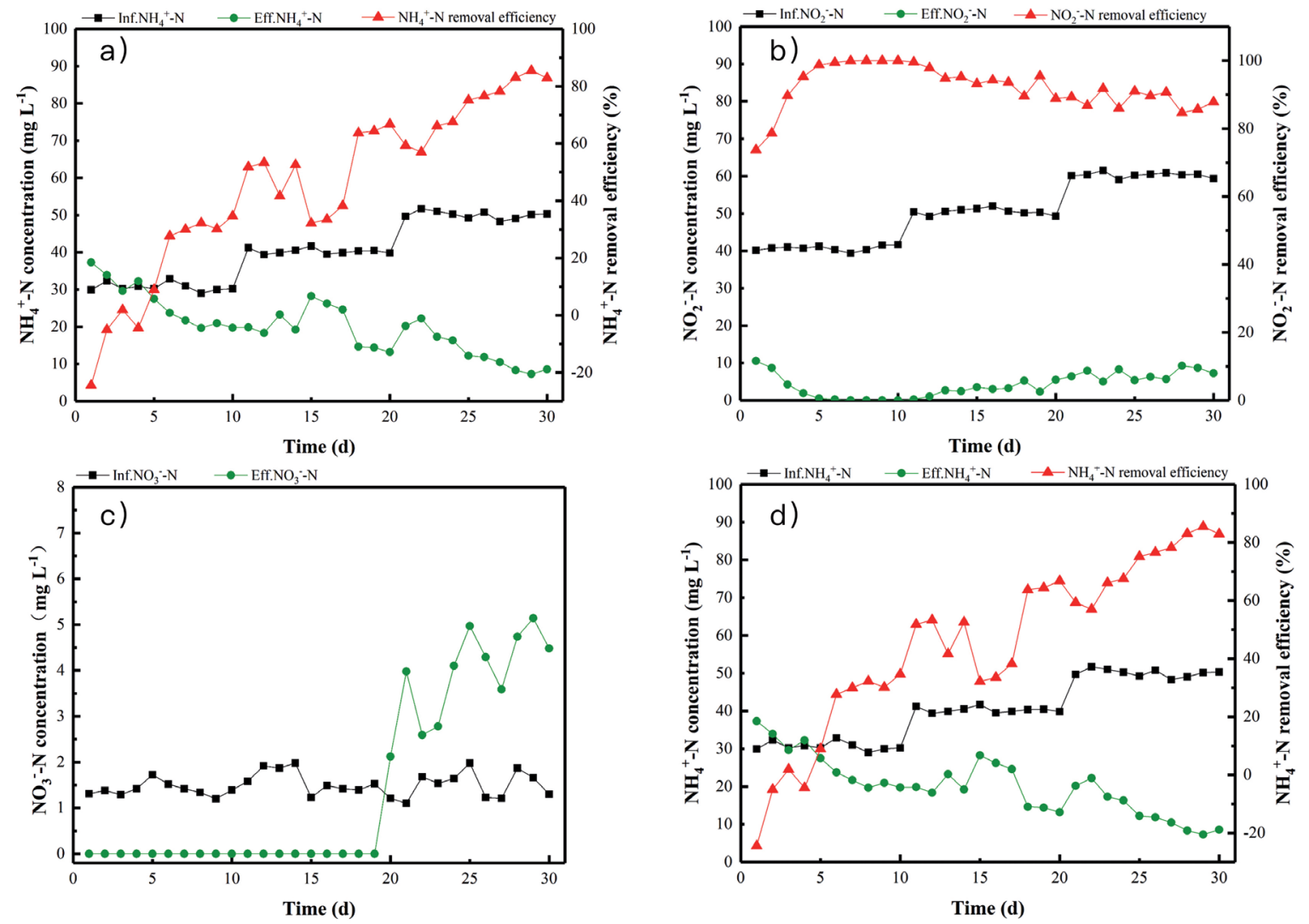

Fig. 3. Nitrogen removal performance during the start-up of UASB: a) Concentration variation and removal rate of NH4+-N; b) Concentration variation and removal rate of $\mathrm{NO}_{2}-\mathrm{N}$; c) Concentration variation and removal rate of $\mathrm{NO}_{3}-\mathrm{N}$; d) Concentration variation and removal rate of $\mathrm{TN}$.

was no $\mathrm{NO}_{3}^{-}-\mathrm{N}$ in the effluent. The average removal rate of TN was $36.72 \%$. The $3-4 \mathrm{~d}$ was in the activity lag phase. The $\mathrm{NH}_{4}^{+}-\mathrm{N}$ concentration and nitrite influent concentration were kept unchanged in this phase. In the $3 \mathrm{~d}$, the effluent concentration of the $\mathrm{NH}_{4}^{+}-\mathrm{N}$ began to be lower than that of the influent, and the removal rate was $1.89 \%$. On the $4 \mathrm{~d}$, the effluent concentration of the $\mathrm{NH}_{4}^{+}-\mathrm{N}$ was a little higher than that of the influent, and the removal rate was negative again. Meanwhile, the effluent concentration of the $\mathrm{NO}_{2}^{-}-\mathrm{N}$ continued to be reduced to $3.07 \mathrm{mg} \mathrm{L}^{-1}$. The effluent concentration of $\mathrm{NO}_{3}^{-}-\mathrm{N}$ was zero, and the average removal rate of $\mathrm{TN}$ was $52.34 \%$.

The 5-30 d was in the activity elevation phase. In this phase, the concentrations of the $\mathrm{NH}_{4}^{+}-\mathrm{N}$ and $\mathrm{NO}_{2}^{-}-\mathrm{N}$ were respectively elevated to $40 \mathrm{mg} \mathrm{L}^{-1}$ and $50 \mathrm{mg} \mathrm{L}^{-1}$ on the $11 \mathrm{~d}$, and elevated to $50 \mathrm{mg} \mathrm{L}^{-1}$ and $60 \mathrm{mg} \mathrm{L}^{-1}$ on the $21 \mathrm{~d}$. The removal rate of $\mathrm{NH}_{4}^{+}-\mathrm{N}$ rose to $34.69 \%$ from $9 \%$. The effluent concentration of nitrite continued to reduce to $0 \mathrm{mg} \mathrm{L}^{-1}$. During the $11-20 \mathrm{~d}$, the $\mathrm{NH}_{4}^{+}-\mathrm{N}$ removal rate gradually rose and rose rapidly from $38.28 \%$ to $63.74 \%$ on the $18 \mathrm{~d}$. The $\mathrm{NO}_{2}{ }^{-}-\mathrm{N}$ effluent concentration was slightly increasing and rose to $5.49 \mathrm{mg} \mathrm{L}^{-1}$. During the 21-30 $\mathrm{d}$, the removal rate of $\mathrm{NH}_{4}^{+}-\mathrm{N}$ was slightly reduced after its load was increased, and later gradually increased, its maximum proportion being $85.49 \%$; the effluent concentration of $\mathrm{NO}_{2}^{-}-\mathrm{N}$ kept increasing and rose to the maximum of $9.28 \mathrm{mg} \mathrm{L}^{-1}$. In addition, after $20 \mathrm{~d}, \mathrm{NH}_{4}^{+}-\mathrm{N}$ was discharged from the effluent, with the amount being between 2.12-5.24 $\mathrm{mg} \mathrm{L}^{-1}$. The nitrogen removal capacity of the reactor in this phase was greatly elevated. The TN removal rate was elevated to $74.33 \%$, and the maximum can be $81.91 \%$.

\section{Sludge Variation in the Reactor}

In the cell lysis and activity lag phases, the sludge color and granule diameter in the sludge bed showed no obvious change. Evenly distributed minute bubbles (Fig. 4a) existed among the granules in the sludge bed, which showed that the sludge yield was high and the activity was good.

During the activity elevation phase, the sludge bed gradually changed from bottom up (Fig. 4b), with the color gradually changing from black to brown, and a small amount of red sludge was generated on the bottom of the reactor. According to Tang et al. [31] and Ni et al. [32], in the start-up process of the Anammox reactor, the granular sludge color changed from black to brown and then red. The variation was consistent with the experiment. The characteristic red color due to heme c [33] is always observed in enriched anammox biomass. Heme $\mathrm{c}$ is a very important co-factor participating the 

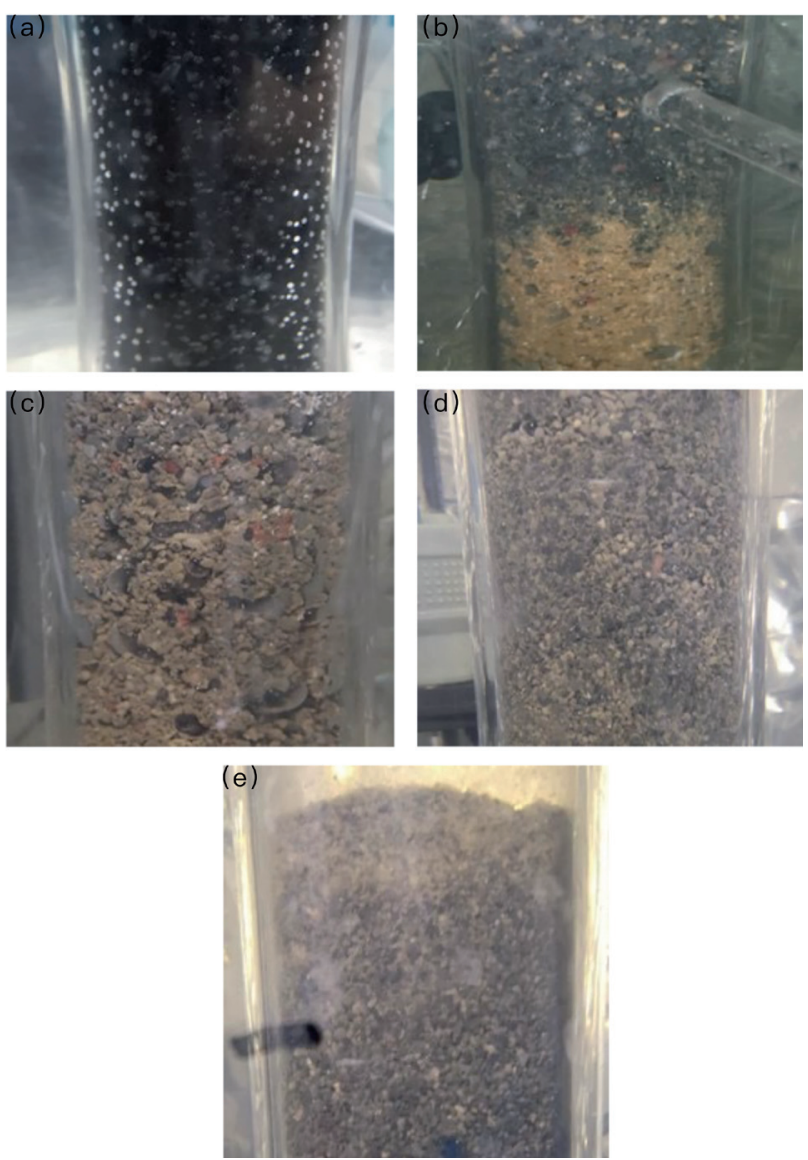

Fig. 4. Sludge bed change in UASB reactor: a) Sludge bed-0d; b) Sludge bed-13d; c) The substratum of the sludge bed-30d; d) The middle layer of the sludge bed-30d; e) The superstratum of the sludge bed-30d. the main metabolic reactions with catalytic and electrontransfer potential in the anammox bacteria, and it is possible to be used as an indicator to evaluate anammox performance [34]. The black sludge in the sludge bed transferred to brown and red sludge was generated, which indicated that the initial start-up of the anammox reactor was successful.

In addition, the sludge in the reactor had obvious stratifications. The granular diameter of the sludge gradually increased from top down. Narnoli et al. [35] had made the UASB reactor granule sludge distribution model diagram (Fig. 5) according to the difference in sedimentation rate, and the distribution law was consistent with this experiment. The unique structure of UASB was influenced by hydraulic shear force and ascending water flow. The hydraulic shear force in the substratum of the UASB was larger than that in the superstratum. The mechanism of sludge nucleation held that [27] high hydraulic conditions can increase the meeting rate of bacteria or the meeting rate between bacteria and inert particles, and thus the nucleation rate can improve and mass transfer can be strengthened, and microorganisms can be promoted to grow. Thus, the granular diameter of the granule sludge in the substratum is larger. Besides, under the sorting action of the ascending water flow, different densities of granule sludge are in graded distribution, and the granular diameter is gradually reduced from the bottom up.

We removed the brown sludge and the red sludge from the reactor for observation (Fig. 6) and found that the structures of the brown sludge and the red sludge are quite loose. Some colonies in the brown sludge and the red sludge were black, which was mainly due
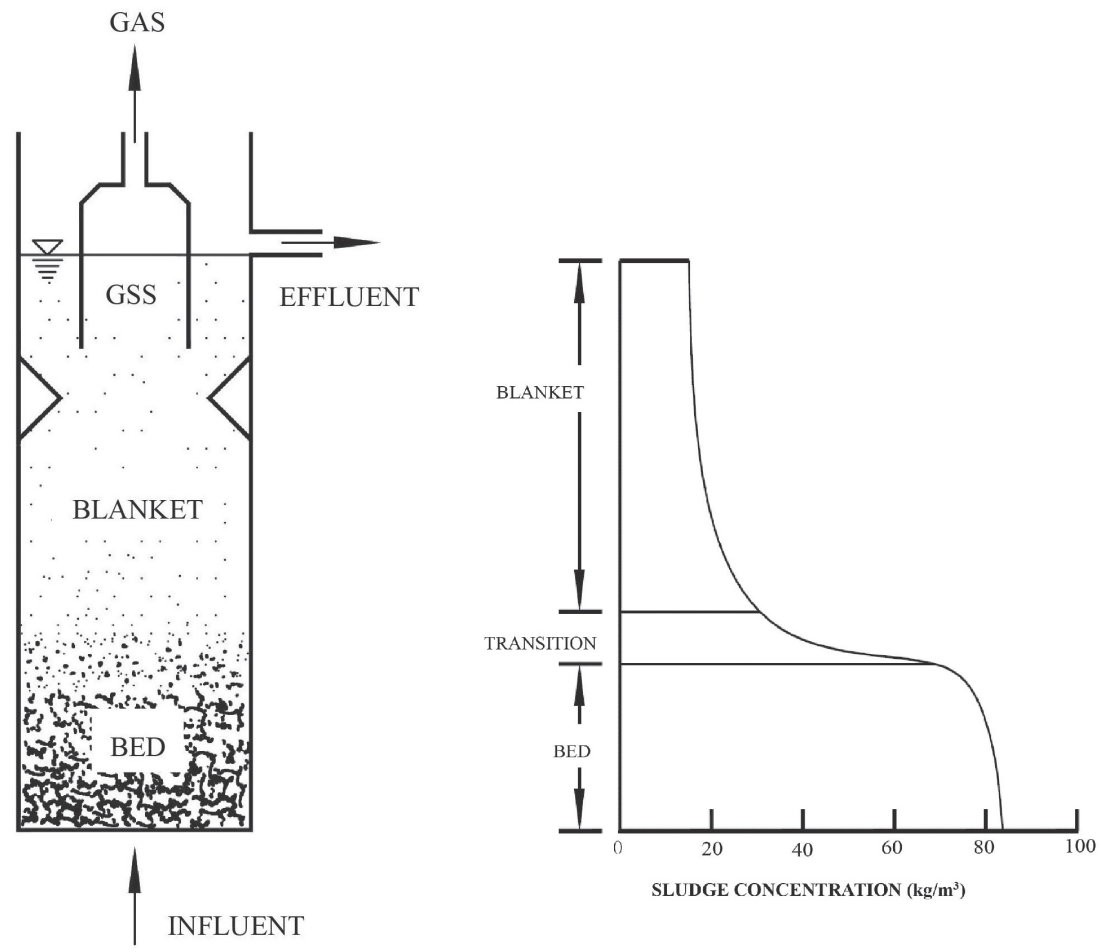

Fig. 5. Schematic diagram of granular sludge distribution in UASB reactor. 

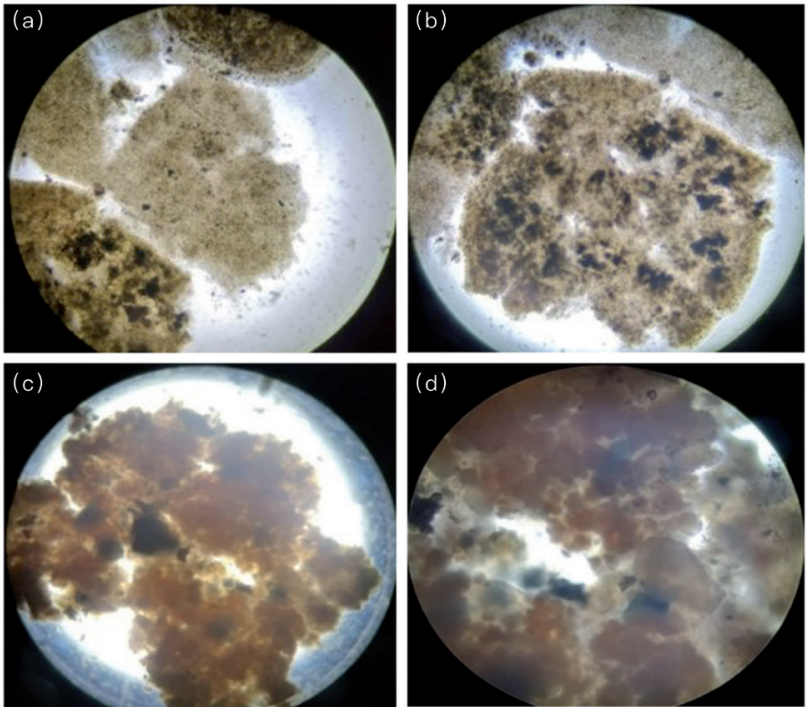

Fig. 6. The microstructure of granule sludge: a) Brown sludge (40×); b) Brown sludge (100×); c) Red sludge (40×); d) Red granule sludge $(100 \times)$.

to the substrate transfer in the wastewater processing that initially happened on the outer layer of the granule sludge and later gradually spread to the inner layer, and hence the variation of the granular sludge was from outside to inside and blended slowly. Moreover, we observed that the red granule sludge consisted mainly of coccus. Zhu et al. [36] believed that AnAOB were mainly in irregular globular shape, and $0.5-0.9 \mathrm{~mm}$ anammox granules drive better performance in lowstrength wastewater treatment.

\section{Nitrogen Removal Mechanism in the Initial Start-up Anammox Process}

\section{Cell Lysis Phase}

1-2 d after the start-up of the reactor was the cell lysis phase. In this phase, the sludge was transferred to current organic-lean condition from original organicrich state. Autolysis happened to some of the bacteria in the inoculated materials as these bacteria could not adapt to the change of environment, which caused the effluent $\mathrm{NH}_{4}^{+}-\mathrm{N}$ to be higher than that of the influent $\mathrm{NH}_{4}^{+}-\mathrm{N}$. In addition, as cell autolysis in the reactor provided an adequate carbon source for denitrification, nitrite and nitrate were removed in the form of denitrification. Yang et al. [37] utilized activated sludge and started up the anammox reactor in the influent mode of low concentration of nitrogen. The cell autolysis phase lasted for $59 \mathrm{~d}$. Yu et al. [38] started up the SBBR reactor by inoculating anaerobic biofilm sludge, and this phase took $27 \mathrm{~d}$. In this research, the cell lysis phase only took two days, which was superior to an ordinary reactor.

The cell lysis phase was comparatively shorter than those in other reports, which could be attributed to three reasons: the first was starting up the reactor with low load, which can make the microorganism adapt to the environment faster and reduce the inhibitory toxic effect caused by the redundancy of nitrous concentrations. Wang et al. [39] took low-concentration nitrogen influent mode (the concentrations of the $\mathrm{NH}_{4}^{+}{ }^{+} \mathrm{N}$ and $\mathrm{NO}_{2}{ }^{-} \mathrm{N}$ were respectively $30 \mathrm{mg} \mathrm{L}^{-1}$ and $40 \mathrm{mg} \mathrm{L}^{-1}$ ) to start up the reactor successfully. Saleem et al. [40], Yin et al. [41], and Zhang et al. [23] all believed that the anammox process should be started up under low loads.

Secondly, repeatedly rinsing the inoculated sludge with buffer solution can effectively reduce nitrogenous organic substance. Yu et al. [38] believed that the organic carbon brought in from the inoculated sludge can lengthen the start-up time. Tang et al. [30] held that the residual organic matter in the inoculated material should be eliminated in the cell lysis phase. Third, anaerobic granule sludge was selected as the inoculated sludge, for this type of sludge consisted of many denitrifying bacteria that can more rapidly utilize the nitrogenous organic compound in the reactor. Moreover, the biodegradability of the sludge from the starch industry was better than other sludge.

\section{Activity Lag Phase}

3-4 d after the start-up of the reactor was the activity lag phase, in which the bacteria did not hydrolyze any more. The influent $\mathrm{NH}_{4}^{+}-\mathrm{N}$ is basically equal to that of the influent. The organic matter generated in the initial period of bacteriolysis provided an electron donor and carbon source for denitrifying bacteria [42]. The concentration of nitrite effluent kept reducing, and the effluent concentration of $\mathrm{NH}_{4}^{+}-\mathrm{N}$ is zero, and denitrification was the main reaction in this phase. The content of AnAOB was low in this phase and the activity lagged, as the autolysis role of bacteria in the initial start-up period caused high content of organic matter in the water. The organic matter promoted the growth of denitrifying bacteria and restrained the growth and reproduction of AnAOB.

Some scholars have classified the cell lysis and cell lag phases into one phase called the cell adaptive phase. The adaptive phase of the first productive anammox reactor [43] in the world was $800 \mathrm{~d}$. In the first $800 \mathrm{~d}$, the nitrogen removal rate of the reactor was $0.025 \mathrm{~kg}-\mathrm{N} / \mathrm{m}^{3} / \mathrm{d}$, while the removal of $\mathrm{NH}_{4}^{+}-\mathrm{N}$ and the generation of $\mathrm{NO}_{3}^{-}-\mathrm{N}$ were not found. However, the cell adaptive phase of this experiment was only $4 \mathrm{~d}-$ far less than the cell adaptive phase of the first productive anammox reactor in the world. The reasons were not only ascribed to the start-up mode, sludge inoculation mode and sludge inoculation source, but also were relevant to the size of the reactor. The device of this experiment was a small setup, in which it was easier to control each parameter. Lv et al. [44] believed that the start-up process of Anammox is essentially the process of survival of the fittest bacteria. Adopt the culture environment fit for the enrichment of anammox, and anammox bacteria can eliminate weak bacteria and 
change the weak bacteria into dominant bacteria. Thus, strictly controlling the $\mathrm{PH}, \mathrm{DO}, \mathrm{T}$ and other operational parameters is the key to starting up an anammox reactor.

\section{Activity Elevation Phase}

5-30 d after the start-up of the reactor is the activity elevation phase. In this phase, the removal rate of $\mathrm{NH}_{4}^{+}-\mathrm{N}$ first increased gradually and then increased rapidly on $18 \mathrm{~d}$, as the anammox phenomenon [45] only appears when the cell concentration of AnAOB reaches a certain proportion. The removal rate of the nitrite took on the trend of increasing first and decreasing later. Substrate competition-nitrite was found between anammox and denitrification, as the large amount of decrement of standard Gibbs free energy can lead to easier gains of nitrite. Moreover, the cell yield (Y) of denitrifying bacteria is $0.27-0.30$ [46], while the cell yield of AnAOB was only 0.066 [47], so denitrifying bacteria can take up the effective space of granule sludge and cause survival space competition [48]. As the increase of the cultivation time, the effluent concentration of $\mathrm{NO}_{2}^{-}-\mathrm{N}$ began to increase, which was mainly because the organic matter generated in the bacteria lysis in stage I had gradually been consumed, and the activity of denitrifying bacteria began to weaken due to the loss of adequate electron donors. This showed that the denitrifying role in the process was weakening, and the denitrifying bacteria were eliminated gradually in washing.

In the first $20 \mathrm{~d}$ of the reaction, $\mathrm{NO}_{2}^{-}-\mathrm{N}$ was not detected in the effluent water, which was mainly caused by two reasons [49]. The first reason was that the $\mathrm{NO}_{2}^{-}-\mathrm{N}$ in the effluent may be reduced to nitrogen by the denitrifying bacteria, and the organic matter needed in the process was gained from the endogenous decay of the microorganism. The second reason was because catabolic nitrate reduction reaction may exist. From the $21 \mathrm{~d}$ of the reaction, when $\mathrm{NO}_{2}^{-}-\mathrm{N}$ can be detected in the effluent, that indicated that the anammox reaction gradually took advantage in the reactor. This was because every $1 \mathrm{~mol}$ of $\mathrm{NH}_{4}^{+}$utilized by AnAOB can generate $0.26 \mathrm{~mol} \mathrm{NO}_{3}^{-}$. When AnAOB took up more ecological niches, the reduction of denitrifying bacteria leads to the $\mathrm{NO}_{3}{ }^{-}$generated by AnAOB not being fully utilized.

\section{Conclusions}

(1) Inoculated anaerobic granular sludge with a UASB reactor started up the anammox process by gradually increasing the load of nitrogen volume. After $30 \mathrm{~d}$ of enrichment, the removal rate of the TN rose from $31.79 \%$ to the maximum of $81.91 \%$. The startup anammox process was actually the process of survival of the fittest, and AnAOB gradually took up a niche advantage.

(2) The duration of cell lysis phase and activity lag phase were comparatively shorter than that of other reports, which was mainly due to the selection of start-up mode, the selection of sludge source, the preprocessing of inoculated sludge and strict control of the operational parameters.

(3) The sludge bed had obvious stratifications: the granular diameter increases from top down; the color of the sludge changed from black to brown, and a small amount of red sludge was generated at the bottom of the reactor. The sludge can be observed with a microscope, and its color gradually changed from outside to inside, showing the process of gradual blending from black to brown and then to red.

\section{Acknowledgements}

This research was funded by the Chinese National Natural Science Foundation (41502333), the China Postdoctoral Science Foundation (2017M610598, 2018T110963), the State Key Laboratory of Geohazard Prevention and Geoenvironment Protection Foundation (SKLGP2018Z007), and the Chengdu University of Technology Scientific Research Projects (2018KJY0230).

\section{Conflicts of Interest}

The authors declare no conflicts of interest.

\section{References}

1. STROUS M., VANGERVEN E., ZHENG P., KUENEN J.G., JETTEN M. Ammonium removal from concentrated waste streams with the anaerobic ammonium oxidation (anammox) process in different reactor configurations. Water Res. 31 (8), 1955, 1997.

2. DU R., CAO S., LI B., NIU M., WANG S., PENG Y. Performance and microbial community analysis of a novel DEAMOX based on partial-denitrification and anammox treating ammonia and nitrate wastewaters. Water Res. 108, 46, 2017.

3. KARTAL B., KUENEN J.G., LOOSDRECHT M.C.M.V. Sewage Treatment with Anammox. Science. 328 (5979), 702, 2010.

4. ZHAO Y., FENG Y., LI J., GUO Y., CHEN L., LIU S. Insight into the Aggregation Capacity of Anammox Consortia during Reactor Start-Up. Environ. Sci. Technol. 52 (6), 3685, 2018

5. TANG C.J., ZHENG P., ZHANG J.Q., CHEN J.W., DING S., ZHOU S.X., DING G.S. Performance and Process Kinetics of Pilot-Scale ANAMMOX Bioreactor Under Different Water Temperatures. Environmental Science. 31 (8), 1834, 2010.

6. LI J., LI J., GAO R., WANG M., YANG L., WANG X., ZHANG L., PENG Y. A critical review of one-stage anammox processes for treating industrial wastewater: Optimization strategies based on key functional microorganisms. Bioresource Technol. 265, S485282848, 2018. 
7. TOMASZEWSKI M., CEMA G., ZIEMBIŃSKABUCZYŃSKA A. Influence of temperature and $\mathrm{pH}$ on the anammox process: A review and meta-analysis. Chemosphere. 182, 203, 2017.

8. DAVEREY A., PANG C.C., DUTTA K., LIN J.G. Statistical analysis to evaluate the effects of temperature and $\mathrm{pH}$ onanammox activity. Int. Biodeter. Biodegr. 102, 89, 2015.

9. LI B., ZHANG W., YAN X., XIN H., YE L. Startup and Performance Stability of a Nitritation-Anammox Reactor Using Granular Sludge. Pol. J. Environ. Stud. 26 (1), 173, 2017.

10. QIN Y., HAN B., CAO Y., WANG T. Impact of substrate concentration on anammox-UBF reactors start-up. Bioresource Technol. 239, 422, 2017.

11. BIN M., SHANYUN W., SHENBIN C., YUANYUAN M., FANGXU J., RUI D., YONGZHEN P. Biological nitrogen removal from sewage via anammox: Recent advances. Bioresource Technol. 200, 981, 2016.

12. LU Y., MA L., LIANG Y., SHAN B., CHANG J. Enhancing Nitrogen Removal Performance in a Bioreactor Using Immobilized Anaerobic Ammonium Oxidation Sludge by Polyvinyl Alcohol-Sodium Alginate (PVA-SA). Pol. J. Environ. Stud. 27 (2), 773, 2018.

13. WANG T., ZHANG H., GAO D., YANG F., ZHANG G. Comparison between MBR and SBR on Anammox start-up process from the conventional activated sludge. Bioresource Technol. 122 (SI), 78, 2012.

14. WANG Q., WANG Y., LIN J., TANG R., WANG W., ZHAN X., HU Z. Selection of seeding strategy for fast start-up of Anammox process with low concentration of Anammox sludge inoculum. Bioresource Technol. 268, 638, 2018.

15. WANG G., DAI X., ZHANG D. Effects of $\mathrm{NaCl}$ and phenol on anammox performance in mainstream reactors with low nitrogen concentration and low temperature. Biochem. Eng. J. 147, 72, 2019.

16. WANG G., DONG Z., YOU X., YU H., DAI X. Comparing two start up strategies and the effect of temperature fluctuations on the performance of mainstream anammox reactors. Chemosphere. 209, 632, 2018.

17. TANG X., GUO Y., JIANG B., LIU S. Metagenomic approaches to understanding bacterial communication during the anammox reactor start-up. Water Res. 136, 95, 2018.

18. CHEN L., LIU S., CHEN Q., ZHU G., WU X., WANG J., LI X., HOU L., NI J. Anammox response to natural and anthropogenic impacts over the Yangtze River. Sci. Total Environ. 665, 171, 2019.

19. ZHAO Z., CAO Y., FAN Y., YANG H., FENG X., LI L., ZHANG H., XING L., ZHAO M. Ladderane records over the last century in the East China sea: Proxies for anammox and eutrophication changes. Water Res. 156, 297, 2019.

20. KUYPERS M.M.M., MARCHANT H.K., KARTAL B. The microbial nitrogen-cycling network. Nat. Rev. Microbiol. 16 (5), 263, 2018.

21. HU Y., HE F., WANG L., SUN J., HUANG T., WU Z. The Fate of Ammonium in Integrated Vertical-flow Constructed Wetlands Using Stable Isotope Technique. Pol. J. Environ. Stud. 25 (3), 1027, 2016.

22. WANG T., WANG X., YUAN L., LUO Z., KWAME INDIRA H. Start-up and operational performance of Anammox process in an anaerobic baffled biofilm reactor (ABBR) at a moderate temperature. Bioresource Technol. 279, 1, 2019.
23. ZHANG J., ZHANG L., MIAO Y., SUN Y., LI X., ZHANG Q., PENG Y. Feasibility of in situ enriching anammox bacteria in a sequencing batch biofilm reactor (SBBR) for enhancing nitrogen removal of real domestic wastewater. Chem. Eng. J. 352, 847, 2018.

24. WANG S., GUO J., LIAN J., NGO H.H., GUO W., LIU Y., SONG Y. Rapid start-up of the anammox process by denitrifying granular sludge and the mechanism of the anammox electron transport chain. Biochem. Eng. J. 115, 101, 2016.

25. TANG C., ZHENG P., CHAI L., MIN X. Characterization and quantification of anammox start-up in UASB reactors seeded with conventional activated sludge. Int. Biodeter. Biodegr. 82, 141, 2013.

26. YANG S., PENG Y., ZHANG L., ZHANG Q., LI J., WANG X. Autotrophic nitrogen removal in an integrated fixed-biofilm activated sludge (IFAS) reactor: Anammox bacteria enriched in the flocs have been overlooked. Bioresource Technol. 288, 121512, 2019.

27. BAETEN J.E., BATSTONE D.J., SCHRAA O.J., van LOOSDRECHT M.C.M., VOLCKE E.I.P. Modelling anaerobic, aerobic and partial nitritation-anammox granular sludge reactors - A review. Water Res. 149, 322, 2019.

28. PEKYAVAS G., YANGIN-GOMEC C. Response of Anammox bacteria to elevated nitrogen and organic matter in pre-digested chicken waste at a long-term operated UASB reactor initially seeded by methanogenic granules. Bioresource Technology Reports. 7, 100222, 2019.

29. APHA. Standard Methods for the Examination for Water and Wastewater, $21^{\text {th }}$ Ed. American Public Health Association, Washington, DC., USA, 2005.

30. TANG C.J., PING Z., TINGTING C. Inoculum, startup and performance of Anammox process. Journal of Chemical. CIESC Journal. 61 (10), 2510, 2010.

31. TANG C., ZHENG P., WANG C., MAHMOOD Q., ZHANG J., CHEN X., ZHANG L., CHEN J. Performance of high-loaded ANAMMOX UASB reactors containing granular sludge. Water Res. 45 (1), 135, 2011.

32. NI S., FESSEHAIE A., LEE P., GAO B., XU X., SUNG S. Interaction of anammox bacteria and inactive methanogenic granules under high nitrogen selective pressure. Bioresource Technol. 101 (18), 6910, 2010.

33. GUO Y., ZHAO Y., ZHU T., LI J., FENG Y., ZHAO H., LIU S. A metabolomic view of how low nitrogen strength favors anammox biomass yield and nitrogen removal capability. Water Res. 143, 387, 2018.

34. MA H., ZHANG Y., XUE Y., ZHANG Y., LI Y. Relationship of heme $\mathrm{c}$, nitrogen loading capacity and temperature in anammox reactor. Sci. Total Environ. 659, $568,2019$.

35. NARNOLI S.K., MEHROTRA I. Sludge blanket of UASB reactor: Mathematical simulation. Water Res. 31 (4), 715, 1997.

36. ZHU G., WANG S., MA B., WANG X., ZHOU J., ZHAO S., LIU R. Anammox granular sludge in low-ammonium sewage treatment: Not bigger size driving better performance. Water Res. 142, 147, 2018.

37. YANG R.L., WANG X.J., WU J.B., GUO Y., ZHANG S.J. Rapid start-up strategy and microbial characteristics of anammox process. Chinese Journal of Environmental Engineering. 12 (12), 3341, 2018.

38. YING-CUI Y.U., GAO D.W., TAO Y., CHEN C.H. Start-up of anammox in a sequencing batch biofilm reactor(SBBR). China Environmental Science. 32 (5), 843, 2012. 
39. WANG G., ZHANG D., XU Y., HUA Y., DAI X. Comparing two start up strategies and the effect of temperature fluctuations on the performance of mainstream anammox reactors. Chemosphere. 209, 632, 2018.

40. SALEEM M., LAVAGNOLO M.C., CONCHERI G., STEVANATO P., SQUARTINI A., SPAGNI A. Application of anaerobic dynamic membrane bioreactor (AnDMBR) for the successful enrichment of Anammox bacteria using mixed anaerobic and aerobic seed sludge. Bioresource Technol. 266, 532, 2018.

41. YIN X., QIAO S., ZHOU J., TANG X. Fast start-up of the anammox process with addition of reduced graphene oxides. Chem. Eng. J. 283, 160, 2016.

42. WANG Q., WANG Y., LIN J., TANG R., WANG W., ZHAN X., HU Z. Selection of seeding strategy for fast start-up of Anammox process with low concentration of Anammox sludge inoculum. Bioresource Technol. 268, 638, 2018.

43. VAN DER STAR W.R.L., ABMA W.R., BLOMMERS D., MULDER J., TOKUTOMI T., STROUS M., PICIOREANU C., Van LOOSDRECHT M.C.M. Startup of reactors for anoxic ammonium oxidation: Experiences from the first full-scale anammox reactor in Rotterdam. Water Res. 41 (18), 4149, 2007.

44. LU G., LI T., XU L., SHEN Y., WU P., ZHANG T., SAMWINE T. Quick Start-up Performance of Combined
ANAMMOX Reactor Based on Different Inoculated Sludge Types. Environmental Science. 38 (10), 4324, 2017.

45. PENG Y., ZHANG X., BIN M.A., JIA F., HAN J. Mechanism of Quorum Sensing in Anaerobic Ammonium Oxidation(Anammox) Bacteria. Journal of Beijing University of Technology. 44 (3), 449, 2018.

46. GAO H., MAO Y., ZHAO X., LIU W., ZHANG T., WELLS G. Genome-centric metagenomics resolves microbial diversity and prevalent truncated denitrification pathways in a denitrifying PAO-enriched bioprocess. Water Res. 155, 275, 2019.

47. STROUS M., HEIJNEN J.J., KUENEN J.G., JETTEN M. The sequencing batch reactor as a powerful tool for the study of slowly growing anaerobic ammoniumoxidizing microorganisms. Appl. Microbiol. Biot. 50 (5), 589, 1998.

48. GUO Y., ZHAO Y., ZHU T., LI J., FENG Y., ZHAO H., LIU S. A metabolomic view of how low nitrogen strength favors anammox biomass yield and nitrogen removal capability. Water Res. 143, 387, 2018.

49. WANG Q., WANG Y., LIN J., TANG R., WANG W., ZHAN X., HU Z. Selection of seeding strategy for fast start-up of Anammox process with low concentration of Anammox sludge inoculum. Bioresource Technol. 268, 638, 2018. 
